\title{
PEREMPUAN DALAM NOVEL DESTROY,SHE SAID KARYA MARGUERITE DURAS: ANALISIS FEMINISME KEKUASAAN NAOMI WOLF
}

\author{
Women in Novel Destroy, She Said by Marguerite Duras: Analysis of Power
} Feminism Naomi Wolf

\author{
Muhammad Fadli Muslimin \\ Fakultas Sastra, Universitas Muslim Indonesia, \\ Jalan Urip Sumoharjo KM.5, Makassar, 082291513675, \\ posel : fadlimuslimin@gmail.com
}

Diterima 23 September 2019

Direvisi 13 Oktober 2019

Disetujui 15 Oktober 2019

\begin{abstract}
Abstrak: Penelitian ini membahas tentang upaya perempuan untuk mendominasi di tengah-tengah dominasi laki-laki. Penelitain ini menggunakan metode kualitatif deskriptif, dengan menggunakan teori feminisme kekuasaan Naomi Wolf. Tujuan penelitian ini adalah mengungkapkan kekuasaan dan fungsi kekuasaan perempuan dalam novel Destroy, She Said karya Merguerite Duras. Hasil penelitian ini menunjukkan bahwa perempuan memiliki kekuasaan yang diperoleh dari pesona diri, sikap tegas, dan ketegaran. Kekuatan tersebut dimafaatkan oleh perempuan untuk mendominasi laki-laki, tetapi dominasi yang dilahirkan tidak menjadikan perempuan superior, melainkan menempatkan perempuan setara dengan laki-laki.

Kata kunci: Perempuan, dominasi, kekuasaan, superior

Abstract : This research raises the issue of women which focuses on women's efforts to dominate amidst male domination. Qualitative research with descriptive methods is utilized, along with the use of the theory of feminism Naomi Wolf's power as a knife of analysis is used to address issues regarding women's power over women and their functions. The purpose of this research is to reveal the power and function of women's power in the novel Destroy, She Said by Merguerite Duras. The results of this study indicate that women have the power gained from self-charm, assertiveness, obstinacy. This power is used by women to dominate men, but the dominance that is born does not make women superior, but rather places women as equals to men.
\end{abstract}

Key word: Women, domination, power, superior

\section{PENDAHULUAN}

Konstruksi budaya terhadap lakilaki dan perempuan telah mengakar kuat di masyarakat. Streotipe yang melekat terhadap salah satu gender, baik laki-laki maupun perempuan, dapat membentuk sikap dalam bertindak di masyarakat, sehingga wacana gender yang kuat mendominasi dan yang lemah tersubordinasi. Hal itu berlaku tidak hanya pada perempuan, tetapi juga berlaku pada laki-laki. Meskipun kenyataannya bahwa perempuan tetap saja ditempatkan lebih rendah dari lakilaki.

Tubuh perempuan dapat dijadikan komoditas politik sebagai bentuk pelemahan terhadap identitas perempuan. Tubuh perempuan dianggap sebagai sesuatu yang berbahaya dan perlu dikendalikan melalui kebijakan terhadap tubuh (Susilo \& Kodir, 2016, hlm. 317). Respon terhadap hal ini memunculkan 
pandangan mengenai perempuan di masa awal kemunculan gelombang feminis untuk memperjuangkan hak-hak perempuan dan kesetaraan gender. Perempuan sebagai manusia memiliki nilai yang sama dengan laki-laki yang melekat padanya. Seiring dengan kemajuan zaman perempuan perlahan melalui pergerakan-pergerakannya mencapai titik kesetaran gender itu bukan lagi angan-angan semata. Hal tersebut, telah melalui perjuangan panjang sehingga perempuan telah mendapat tempat yang dapat dikatakan sejajar dengan laki-laki meskipun dipahami bahwa setiap waktu wacana subordinasi perempuan dapat muncul sewaktu-waktu dengan entitas yang berbeda.

Di saat hak-hak dan kesetaraan perlahan telah diperoleh dari kaum lakilaki, muncul suatu pandangan yang menolak dari dalam perempuan itu. Pergolakan-pergolakan dari dalam yang tidak menginginkan pengidentifikasian antara perempuan yang satu dengan yang lainnya menjadikan polemik tersendiri dari dalam tubuh feminis itu. Tidak saja berjuangan terhadap kaum laki-laki, tetapi juga berjuang untuk mendapatkan tempat di antara perempuan yang lain.

$$
\text { Hal tersebut dianggap }
$$

menghalangi perkembangan kehidupan perempuan. Perempuan tidak perlu bersembunyi dari ketidakberdayaan yang dianggap sebagai pemicu tidak terlibatnya sebagian perempuan dalam pergerakan feminis. Dorongan-dorongan untuk mendominasi, menyerang, menyerobot, atau melakukan eksploitasi terhadap orang lain bukanlah suatu ketetapan yang hanya dimiliki oleh lakilaki, tetapi perempuan juga memiliki hak yang sama untuk berlaku demikian.
Hal ini telah dilakukan oleh perempuan dalam upaya menunjukkan eksistensinya di masyarakat. Women and Power Overcoming Barriers to Leadership and Influence yang ditulis oleh Tam O'Neil dan Pilar Domingo menunjukkan bahwa di seluruh dunia, perempuan saat ini memiliki kekuasaan dan pengaruh untuk mengambil keputusan tehadap berbagai aspek, yaitu sosial, politik, dan ekonomi, daripada sebelumnya (O'Neil \& Domingo, 2016, hlm. 9). Tuntutan persamaan wanita dalam berbagai aspek kehidupan bukanlah sesuatu yang ditawar-tawar lagi.

Bahkan, strategi-strategi untuk memenuhi kesetaraan gender telah mencapai tahap yang di beberapa aspek sangat berkembang melalui kebijakan, investasi dan diplomasi, dan promosi gender di korporasi (Australian Goverment, 2016, hlm.25).

Dalam konteks karya sastra, wacanaa-wacana tersebut secara berkelanjutan direproduksi oleh penulispenulis feminis. Upaya ini merupakan langkah yang ditempuh untuk menunjukkan kritik sekaligus penguatan eksistensi perempuan di tengah-tengah masyarakat yang masih berpaham maskulin. Wahyu Utomo yang melihat gejala tersebut pada novel dreams of trespass karangan Fatema Mernissi tahun 1940. Perjuangan Fatima Mernissi untuk mendobrak patriakal yang berakar dari kehidupan tradisional melalui perjuangan gender untuk mendapatkan kesetaraan (Utomo, 2011, hlm.95)

Memandang bahwa perjuangan tersebut bukanlah sesuatu yang dapat terputus dan keyakinan bahwa Perempuan dan laki-laki memiliki nilai yang sama dalam kehidupan manusia, oleh karena itu perempuan mampu untuk melakukan segala sesuatu yang 
mereka kehendaki tanpa memandang laki-laki sebagai pusat. Sebagai seorang feminis, menjadi kuat bagi perempuan adalah sebuah kewajiban, setidaknya hal ini merupakan langkah yang dikonstruksikan terhadap perempuan untuk melawan laki-laki, dalam sebuah novel karya Marguerite Duras yang berjudul Destroy, She Said.

Dalam Novel Destroy, She Said dapat ditemukan hal-hal yang bersifat misterius, berbahaya, suasana muram, tekanan psikologis, magis, dan juga mengenai perempuan. Novel ini mengajak pembacanya melihat sisi lain dari kota Prancis berupa latar hutan. Duras menampilkan empat tokoh yang menjadi pusat dalam cerita, yaitu Stein, Max Thor, Alissa, dan Elisabeth Alion. Fokus analisis novel ini adalah tokoh perempuan Alissa dan Elisabeth Alion. Narasi yang dibangun oleh Duras sebagai penulis perempuan, yaitu penggambaran sosok perempuan dalam cerita sejajar dengan laki-laki. Bahkan terdapat kecenderungan memandang kaum laki-laki sebagai pusat yang tersubordinasi meskipun telah mendapat tempat di masyarakat.

Uraian serupa yang mengangkat perempuan sebagai obyek dalam novel, yaitu pada penelitian yang dilakukan oleh Yoga Rohtama, dkk,. Dalam penelitian yang berjudul Tokoh Utama dalam Novel Pelabuhan Terkahir karya Roidah: Kajian Feminisme Liberal. Dengan memanfaatkan konsep dasar feminisme Naomi Wolf yang meletakkan pada kekuasaan tokoh utama, ia mencoba menggambarkan subordinasi perempuan dalam budaya patriarki. Konsep yang digunakan lebih dekat pada feminisme liberal, meskipun pada dasarnya dapat pula dikatakan sebagai feminisme kekuasaan. Landasannya terletak pada kebebasan yang dimiliki individu, baik laki-laki ataupun perempuan, untuk menentukan pilihan (Yoga, Akhmad, \& Dahri, 2018, hlm.221).

Apa yang ditemukan oleh Dominique Hecq dalam tulisannya yang berjudul May 68: Parodic reherasals of the future in Lacan and Duras terkait novel Destroy, She Said merupakan analisis yang berbeda. Ia menganggap bahwa novel ini merupakan bentuk parodi masa depan dalam konteks sosial politik. Ia berpendapat bahwa novel ini merupakan upaya Duras melahirkan teks revolusionis pada masanya di tahun 1970. Duras menampilkan dorongan transgresif dan kekuasaan (Campbell, Hecq, Keane, \& Pont, 2015, hlm.1).Berdasarkan latar belakang tersebut, masalah yang akan dibahas dalam kajian ini ialah bagaimana kekuasaan perempuan terhadap laki-laki dalam novel dan fungsi kekuasaan tersebut dalam relasinya dengan kaum laki-laki. Tujuan penelitian ini adalah mengungkapkan ruang lingkup kekuasaan perempuan terhadap laki-laki dan fungsi kekuasaan dalam novel Destroy, She Said.

\section{KERANGKA TEORI}

Wolf menempatkan laki-laki dan perempuan setara sebagai manusia lengkap dengan nilai yang dilekatkan. Wolf menegaskan bahwa salah satu gender tidak dapat dianakemaskan. Lebih lanjut ia menjelaskan bahwa siapapun yang memperjuangkan masalah perempuan harus berupaya keluar dari tradisi pemikiran barat yang menyatakan bahwa manakala satu sama lain berbeda maka mereka saling memangsa. Perbedaan pendapat antara sesama perempuan bukan berarti harus saling menyerang satu dengan yang 
lainnya. Menurut Wolf, setiap gerakan perempuan dipadukan satu sama lain dengan berdasarkan pada persamaan dan tetap mempertahankan keberagamaan untuk memperkaya nuansa feminis layaknya mozaik. Jadi, ketika gerakan perempuan dalam bingkai baru muncul, bingkai tersebut dapat diperbesar secara fleksibel (Wolf, 1997, hlm. x-xii).

Dalam era keterbukaan, perjuangan perempuan yang cukup panjang untuk memperoleh kesetaraan gender telah sampai ke tahap dimana perempuan memiliki keyakinan untuk menyeimbangkan kekuasaan antar gender. Namun, hal itu menimbulkan kendala yang menghalangi kemajuan gerakan feminis. Naomi Wolf (1997) menambahkan bahwa banyak perempuan terasing dari gerakan kaumnya sendiri. Sebuah cabang feminisme telah memicu dan memunculkan sikap-sikap yang keliru dan kita tak cukup dibekali ilmu kejiwaan tentang kekuatan perempuan untuk mengimbangi kesempatankesempatan baru yang membentang di depan mata (hlm. xxiii).

Selanjutnya, Wolf menegaskan bahwa perempuan mempunyai hak untuk mencapai presetasi dan kekuasaan. Dalam pandangannya, untuk mencapai kekuasaan, perempuan harus melalui dua tradisi, yaitu feminisme korban dan feminisme kekuasaan. Feminsme korban menurut Wolf dapat memperlambat kemajuan perempuan dan menempatkannya sebagai korban.

Feminisme korban dapat dianggap usang lantaran kondisi kejiwaan dan kondisi-kondisi kehidupan perempuan telah berubah cukup banyak, sehingga tidak mungkin lagi berpura-pura bahwa dorongan-dorongan

untuk mendominasi, untuk menyerang, meyerobot atau melakukan eksploitasi atas diri orang lain adalah 'merek dagang' kaum laki-laki semata (Wolf, 1997, hlm.xxv).

Sedangkan feminisme kukuasaan prinsipnya adalah (1) perempuan dan laki-laki sama-sama memiliki peran yang besar dalam kehidupan, (2) perempuan berhak menentukan nasib sendiri, (3) pengalaman perempuan bermakna, bukan sekadar omong kosong yang tidak penting, (4) perempuan berhak mengungkapkan kebenaran tentang pengalamannya, (5) perempuan layak menerima rasa hormat dari orang lain, rasa hormat terhadap diri sendiri, pendidikan, keselamatan, kesehatan, keterwakilan, dan keuangan (Wolf, 1997, hlm.204).

Konsep feminisme kekuasaan yang ditawarkan oleh Naomi Wolf menjadi landasan dalam menganalisis Novel Marguerite Duras Destroy, She Said.Metode yang dipergunakan adalah metode analisis isi yang memfokuskan terhadap isi laten yang terdapat dalam teks novel. Isi laten yang dimaksud adalah isi yang terkandung dalam novel sebagaimana yang dimaksudkan oleh pengarang. Dasar yang digunakan pada novel ini adalah sebuah penafsiran yang memberikan perhatian terhadap isi dari pesan.

\section{METODE PENELITIAN}

Penelitan ini merupakan penelitian kualitatif. Proses sistematis dilakukan untuk menjawab rumusan masalah yang telah disajikan sebelumnya berlandaskan pada data-data yang diperoleh dari obyek material.

Proses sistematis yang dimaksud merupakan kegiatan yang dilakukan dengan prosedur yang ditetapkan secara 
tertata (tersistem). Prosedurnya mengikuti urutan tertentu (Pradopo et al., 2003, hlm.2). Urutan yang dimaksud dinyatakan sebagai berikut.

Perumusan masalah $>>$ penelaahan informasi $>$ pengumpulan data $>>$ analisis data $>>$ penyajian kesimpulan

Urutan tersebut diuraikan sebagai berikut: 1). Merumusukan permasalahan dalam novel berdasarkan pembacaan terhadap novel dan teori. 2) Menelaah informasi-informasi yang terdapat dalam teks. 3) Data dikumpulkan dari novel karangan karangan Marguerite Duras yang berjudul Destroy She Said. Penelaahan dilakukan terhadap novel tersebut, selanjutnya ditentukan objek formalnya, yakni berfokus pada kekuasan perempuan terhadap laki-laki. Data-data dari penelitian ini diperoleh dari teks yang berbentuk kutipankutipan yang relevan dari sudut pandang kekuasaan perempuan. Selanjutnya, data dianalisis menggunakan teori dari Naomi Wolf.Yaitu feminisme kekuasaan yang memuat unsur-unsur kekuasaan perempuan dalam teks dideskripsikan dan dicari hubungannya berdasarkan kaidah-kaidah logis serta disajikan secara deskriptif. 4) Penyajian simpulan, yakni penarikan simpulan berdasarkan analisis dan interpretasi terhadap data serta menjawab secara langsung permasalahan.

\section{HASIL DAN PEMBAHASAN}

Novel ini merupakan novel klasik karya Marguerite Duras tahun 1970. Penulis adalah seorang novelis perempuan berkebangsaan Perancis. Selain menulis novel, ia juga seorang penulis naskah, esai, dan pembuat film eksperimental. Novel ini bercerita tentang subversif terhadap keyakian, keluarga, kemandirian, dan penyalahgunaan perempuan.

Pada bagian pembahasan ini menguraikan bagaimana perempuan dalam konteks sosial masyarakatnya menunjukkan kekuatan-kekuatan yang dimiliki perempuan dalam novel Destroy She Said (Duras, 1970), yaitu Alissa dan Elisabeth Alion. Kekuatan tersebut memungkinkan tokoh-tokoh perempuan berdiri pada posisi yang sejajar dengan tokoh laki-laki.

Upaya yang coba dibangun oleh penulis di dalam novel merupakan upaya menghancurkan penghalang yang diciptakan oleh struktur hierarkis dan patriakal (Gumelar \& Mukhroman, 2015, hlm.71) Penghalang-penghalang tersebut secara kultural telah melekat di masyarakat. Namun, esensi yang ingin dibangun bukanlah upaya meruntuhkan struktur secara utuh, melainkan penekanan pada bagaimana kekuatan tersebut diaktualisasi.

Pada tahap perempuan memperoleh kekuasaan tersebut, perempuan memegang kekuasaan, dipuja dan dihormati oleh lelaki serta melihat perpaduan perempuan berdasarkan kesamaan, mereka membangun diri sebagai perempuan yang berada diantara lelaki tanpa melakukan praktik subordinasi terhadapnya.

Hal lainnya yang dibahas adalah fungsi kekuasaan yang dimiliki perempuan. dengan mengandalkan kekuatan yang dimiliki apakah yang mampu untuk dilakukan oleh perempuan di tengah-tengah pergulatan interaksinya dengan laki-laki. 


\subsection{Kekuatan-Kekuatan Perempuan}

Feminis yang ditawarkan oleh Wolf menghadirkan dua tradisi feminis, yaitu feminisme korban dan kekuasaan yang dapat dimanfaatkan bagi perempuan untuk memperoleh kekuasaan. Feminisme korban menempatkan ketidakberdayaan sebagai alat untuk memperoleh kekuasaan, tetapi langkah ini dianggap oleh Wolf sebagai biang melambatnya perkembangan kemajuan feminis dan cenderung bersifat regresif. Feminsime korban memperlambat kemajuan perempuan, merintangi pengetahuan akan diri sendiri dan bertanggung jawab atas sebagaian besar pola pikir yang tidak konsisten, negativ, sovinistis, dan regresif atau membawa kemunduran (Wolf, 1997, hlm.199)

Analisis novel ini berfokus pada upaya yang dilakukan perempuan dalam perspektif feminisme kekuasaan. Perempuan dan laki-laki memiliki arti yang sama di dalam kehidupan. Perempuan berhak menentukan dirinya sendiri. Pengalamam perempuan dijadikan refleksi dalam memandang kekuatan yang bersumber dari dalam dirinya.

Narasi yang dibangun oleh Duras dalam novelnya mengenai kekuatankekuatan pada perempuan dan relasinya. Narator dalam hal ini adalah Duras sebagai penulis menarasikan kekuatan perempuan di awal cerita mengenai paras fisik perempuan tersebut dengan segala kelebihan yang dimiliki, mesikupun dinyatakan oleh narator bahwa perempuan tersebut tidak dalam keadaan yang cukup baik meskipun demikian pesona yang dimiliki perempuan tersebut

$$
\begin{array}{clr}
\text { "Dia menyadari betapa } \\
\text { memesonanya cara perempuan itu }
\end{array}
$$

berpakaian, sosoknya menarik, caranya bergerak, caranya berbaring di halaman setiap hari, juga kedua tangannya".(Duras, 1970, hlm.2)

Anggapan yang dibangun mengenai kekuatan perempuan lahir dari dalam diri, yaitu pernyataan mengenai sosok yang menarik dan citra tubuh yang ditampilkan melalui pakaian. Hal yang dilakukan tokoh perempuan tersebut tidak terlalu berdampak signifikan, tetapi memperkuat citra diri melalui penampilan demi memperoleh kekuatan tersebut.

Selain citra fisik, kekuatan perempuan juga ditampilkan sebagai alat pengontrol sikap dalam pengambilan keputusan. Kekuatan tersebut bersumber dari kemampuan diri yang secara sadar menerima ajakan lelaki. Meskipun hal tersebut hanya sekadar ajakan berbincang mengenai suatu hal. Kehendak yang tegas menyebabkan lakilaki tidak dapat bersikap semaunya. Ada mekanisme diri perempuan yang membatasi.

"Anda belum menjawab pertanyaan saya. Mengapa hari ini?" akhirnya lelaki itu menatapnya. "Kau sudah mengira?" "Begitulah". Lelaki itu bangkit, membuat isyarat ajakan" bisa kita berbincangbincang dekat jendela?" "Tidak ada gunanaya." "Baiklah". ( Duras, 1970, hlm.7)

Laki-laki tersebut tidak melakukan apa-apa terhadap penolakan yang dilakukan oleh perempuan. Penolakan tersebut menjadi kekuatan tersendiri dan berdampak secara langusung terhadap laki-laki.

Ketegaran juga menjadi kekuatan dari seorang perempuan, betapa seorang perempuan yang dianggap lemah dan 
tidak mampu berbuat apa-apa jika disandingkan dengan laki-laki menunjukkan dirinya, meskipun sebagai seorang perempuan, tetapi ada hal dari dalam dirinya yang menuntut untuk tidak diidentifikasikan dengan streotipe yang dilekatkan kepada perempuan mengenai lemahnya perempuan, bahwa perempuan juga mampu untuk bertahan dari peristiwa yang mengguncanggkan diri.

"Latar belakangnya dari golongan menengah,' kata Alisa. "Suaminya mungkin punya usaha sendiri. dia pasti sudah menikah di usia sangat muda dan langsung punya anak perempuan... katanya ia takut diabaikan. Dia pun mengulang-ulang cerita tentang bayinya yang mati." (Duras, 1970, hlm.49)

Narator mencoba menarasikan perempuan sebagai sosok yang tegar dan itu dijadikan sebagai kekuatan. Menikah di usia dini dan mempunyai anak di usia yang relatif muda memberikan dampak psikologis yang menggoyahkan mental muda tersebut. Namun, sikap tegarnya menunjukkan dia mampu lepas dari belenggu masa lalu.

"Setelah persalinan kutunjukkan surat itu pada suamiku. Dan saat itulah dia menyadari apa yang telah kulakukan yang membuatnya sadar bahwa... semuanya sia-sia dan dia mencoba membunuh diri" ( Duras, 1970, hlm.68)

Narator mengkonstruksi kekuatan perempuan tersebut melalui kutipan diatas bahwa laki-laki yang dianggap selalu kuat dan memiliki mental yang lebih daripada perempuan dinyatakan betolak belakang dengan yang terjadi dengan Alissa. Suaminya tidak mampu menanggung beban ketika mengetahui bahwa bayi yang dikandung istrinya mati sebelum dilahirkan. Dia mencoba bunuh diri, sedangkan Alissa tetap tegar. Ketegaran yang ditunjukan oleh Alissa tidak lain terjadi karena dorongan dari dalam dirnya.

\subsection{Kekuasaan Perempuan terhadap Laki-laki}

Feminisme kekuasaan ingin menyertakan lebih banyak lagi perempuan. Ideologi yang dijunjungnya luwes dan inklusif, bersifat melingkupi. Feminisme kekuasaan menyatakan bahwa perempuan layak mendapatkan rasa hormat dari orang lain, rasa hormat terhadap diri sendiri, pendidikan, keselamatan, kesehatan, keterwakilan, dan keuangan. (Wolf, 1997, hlm. 204).

Dalam novel ini, kelayakan perempuan tersebut dapat diamati pada kutipan berikut.

"I thought you had no attachments outside the hotel." He smiles. "No one ever phones you. You don't get any letters. And nowhere all of a sudden Alissa is going to put in an appearance."

She halts by a path-the path that leads to the forest-hesitates, then walks toward the porch of the hotel (Duras, 1970, hlm. 56).

Pada kutipan tersebut, tokoh perempuan menekankan rasa hormat pada dirinya sendiri. Ia tinggal di hotel selama beberapa minggu untuk menjaga privasi dirinya sendiri

Kemajuan perempuan dalam tingkat partisipasi di berbagai bidang tidak hanya menyentuh ruang domestik melainkan juga ruang publik. Hal ini membuat perempuan memiliki kekuasaan di dalam dirinya, sehingga pemaknaan mengenai perempuan beranjak ke arah yang positif. Dalam novel ini, kekuasaan perempuan masih 
terbatas pada ruang lingkup domestik. Relasi antara laki-laki dan perempuan terbatas pada tataran kehidupan seharihari.

Kekuatan perempuan yang telah dikonstruksi oleh Duras melahirkan citra perempuan yang tangkas dan tangguh. Keadaan ini menciptakan laki-laki yang terdampak langsung sebagai akibat perubahan besar yang terjadi pada perempuan. Narasi yang terbangun menciptakan dimensi makna yang sama antara laki-laki dan perempuan. Kekuasaan tidak lagi berjalan timpang dan cenderung memojokkan perempuan.

Tubuh menjadi konsep daya tarik bagi perempuan. Atribut yang melekat pada perempuan dikonstruksi oleh budaya patriakal berdasar pada prinsip komoditas. Oleh Duras, hal ini dimanfaatkan menjadi kekuatan bagi perempuan itu sendiri. Pesona diri perempuan dijadikan kekuatan di ruang publik untuk mendapatkan kesetaraan bersanding dengan laki-laki.

Kekuasaan yang dibangun melalui pesona diri yang dibentuk oleh budaya patriakal dimanfaatkan sebagai pemikat laki-laki. Dalam meneorikan tubuh, tindakan memiliki kaitanan secara khusus terhadap perempuan, karena secara konvensional gender melekatkannya dengan tubuh (Gamble, 2010, hlm.147). Dengan demikian, pernyataan tentang dominasi laki-laki terhadap perempuan dapat didekonstruksi. Pada saat yang sama kekuasaan terbagi. Laki-laki tidak mampu mendominasi secara langsung dengan maskulinitasnya dan perempuan tidak mampu melakukan kontrol terhadap laki-laki dengan pesonanya.

Kemampuan pengontrolan yang dimiliki perempuan merupakan bentuk kekuasaan. Apa yang dikontrol adalah relasi yang antara perempuan dan lakilaki dalam komunikasi. Dengan sikap tegas, perempuan memberikan penolakan terhadap ajakan obrolan dari laki-laki. Meskipun tidak berkontribusi besar dalam peniadaan dominasai, hal ini cukup memberikan ruang bagi perempuan untuk bereaksi. Laki-laki pun tidak mampu mengopersi melalui ujaran ataupun tindakan fisik sebagai bentuk pemaksaan terhadap hasrat dan keinginannya.

Kekuasaan perempuan terhadap laki-laki juga diperoleh dari diri mereka sendiri. Pengalaman-pengalaman yang dimilikinya mempunyai makna penting bagi eksistensinya. Pengalamanpengalaman tersebut menjadikan perempuan kuat dan mampu membangun kekuasaannya tersendiri. Kekuasaan yang dimaksud bukanlah diri terhadap tubuh laki-laki atau internalisasi nilai-nilainya, melainkan kekuasaan yang bersumber dari dalam yang diwujudkan melalui sikap tegar. Sikap yang sejatinya dilekatkan kepada kaum laki-laki, seperti yang kuat, perkasa, gigih, dan tegar, juga dimiliki oleh perempuan. Hal tersebut tidak lantas menjadikan perempuan mendominasi keadaan dan menjadikan laki-laki lantas tersubordinasi, melainkan hanya memperkukuh posisi perempuan dan kekuasaannya dalam menjalin interaksi sosial dengan laki-laki. Hal ini menyebabkan hilangnya streotipe perempuan lemah dan hanya bisa mengandalkan laki-laki dalam hal ini. Perempuan juga mampu maju dan bergerak dengan sikap tegar ketika menghadapi perosoalan yang cukup berat berkaitan dengan kehilangan sesuatu yang dimiliki. 


\subsection{Fungsi kekuasaan perempuan}

Apa yang sesungghunya diinginkan perempuan dengan kekuasaan yang telah diraihnya tersebut, menjadi pertanyaan yang dikemukakan di kalangan perempuan sendiri, bagi yang merasa terasing dengan wujud kekuasaan bagi perempuan, Wolf menyatakan bahwa mengejar kekuasaan dan menggunakannya secara bertanggung jawab, baik demi kepentingan perempuan sebagai pribadipribadi maupun untuk membuat dunia jadi lebih adil bagi orang-orang lain (Wolf, 1997, hlm.202). George L. Mosse dalam buku The Image of Man : the Creation of Modern Masculinity mengidentifikasi latar belakang perempuan mengejar kekuasaan. Ia menyatakan bahwa the female was a step below the male, for in the process of conception, woman was an object of male power (L. Mosse, 1996, hlm.55). H al ini tentu berbeda dengan upaya yang ingin diwujudkan oleh perempuan yakni tidak adanya kecenderungan untuk mendominasi melalui kekuasaan yang diperoleh oleh perempuan melalui serangkaian kekuatan-kekuatan yang diperolehnya menjadikan cita-cita untuk keadilan bagi orang lain pun dapat diperoleh.

Pertama, perempuan dalam novel ini kekuasaanya berfungsi sebagai preventif dominasi laki-laki terhadap perempuan. Hal ini dapat diamati pada dialog antara Rivette dan Duras

Rivette: And That Moment is the point of greates intensity in your film, and after itu...

Duras: To meit's the moment yes, there's no doubt that it's the one that's most important. "We could love you too." When they tell him that, they are being absolutely sincere.
Aggression had to be prevented. They are indiscreet. They are immodest (71)

Konstruksi citra diri berupa pesona mampu membuat laki-laki kehilangan dominasinya terhadap perempuan dan menyetarakan laki-laki dan perempuan. Perempuan pun dengan kuasa tersebut tidak lantas mendominasi laki-laki, melainkan mengkehendaki dirinya untuk berlaku sesuai dengan nilai yang melekat padanya.

DURAS: But it's a hope that I'm expressing. I hope that there will be more and more madmen: I makethis statement with pleasure, with satisfaction. Personally. It proves that the solution is near. The premises of a solution. Because I know that we are very, very far away. But here we touch on the problem of freedom. This very moment. We're on the very edge of it

RIVETTE: What disturbs me is the fact that people don't want to think about the work that the person must do, work that your will sets beforeyou at the zero point. I believe there is no escaping the work one has to do on oneself, by oneself.

DURAS: But is this workin the strict sense? You know that work was invented in the nineteenth century

RIVETTE: No, I'm speaking of a kind of work (Duras, 1970, hlm.90).

Kedua, kekuatan dari dalam diri perempuan membuatnya dapat memegang kendali terhadap tanggapan yang dilontarkan laki-laki. Hal ini dapat ditemukan pada percakapan antara Narbone dan Duras tentang Freud and Marx.

NARBONI: But that brings up two questions that I'd like to ask you. The first, which is clearly anecdotal: when you say "Freud and 
Marx today are classified as historical monuments, "do you mean by that there is a certain fetishism that operates where they're concerned, that completely paralyzes their thought, or that refers to it as if it were dogma.

DURAS: What I meant was the Freud used for psychoanalytic ends. Freud can't be read freely. Reading Freud is not within everybody's reach. It ought to be especially since Freud is easy to read. But our reading of Freud is already a prey of worldwide interpretation. Yes: when you come down to it, what I said was facile (Duras, 1970, hlm.65)

Kekuatan dari dalam yang termanifestasi ke dalam ilmu pengetahuan tersebut memberikan posisi perempuan dalam konteks pengetahuan yang setara terhadap laki-laki. Hal yang ingin digoyahkan dalam tradisi patriakal adalah supremasi laki-laki yang diutarakan oleh Zillah $\mathrm{R}$ Eisenstein sebagai kekuatan dinamik. Hal ini melibatkan kapitalisme yang menjalin hubungan kelas produksi untuk memberikan hierarki pada hubungan keduanya (Eisenstein, 1979, hlm.1). Potret yang ingin disampaikan oleh pengarang novel tentang perempuan merupakan reaksi dialogis terkait hal tersebut.

Adapun yang menjadi poin pembeda adalah ketika perempuan berpengetahuan memegang kendali. Hal yang terjadi, perempuan tidak berfungsi sebagaipemegang kendali terhadap eksistensi laki-laki, melainkan perempuan berfungsi sebagai penggerak.

Pengetahuan merupakan konsep abstrak, tetapi memiliki dampak yang luar biasa. Ettor Bolisani berupaya mendefinisikan pengetahuan hingga dia sampai pada kesimpulan bahwa pengetahuan adalah kebenaran yang diyakni. Pengetahuan dibentuk melalui pertemuan sonsorik dengan dunia nyata dan diproses oleh pikiran (Bolisani \& Bratianu, 2018). engetahuan yang diperoleh oleh tokoh perempuan menjadi jembatan perempuan untuk memediasi dirinya dengan lingkungan patriakal.

DURAS: But it's a hope that I'm expressing. I hope that there will be more and more madmen: I make this statement with pleasure, withsatisfaction. Personally. It proves that the solution is near. The premises of a solution Because I know that we are very, very far away. But here we touch on the problem of freedom. This very moment. We're on the very (Duras, 1970, hlm.130)

Meskipun dalam lingkungan domestik, perempuan mulai beranjak dari keterasingan dirinya untuk melangkah maju menyetarakan diri sendiri. Harus disadari bahwa dalam diri setiap perempuan terdapat kekuatankekuatan yang kualitasnya tidak kalah dari kaum laki-laki.Cita-cita kesetaraan gender dapat tercapai dan mengantarkan perempuan mempunyai tempat yang sejajar dengan laki-laki melalui kekuatan-kekuatan dari dalam dirinya sendiri.

\section{PENUTUP}

Dalam novel Destroy, She Said karya Marguerite Duras, perempuan digambarkan mempunyai kekuatankekuatan yang bersumber dari dalam dirinya. Kekuatan tersebut berupakemampuan pesona diri yang dimiliki perempuan. Tidak hanya dari 
pesona diri, kemampuan mengontrol laki-laki melalui sikap tegas juga ditunjukan kepada laki-laki, dan kekuatan lain yang bersumber dari dalam. Yaitu ketegaran yang tidak dimiliki pada pria menghadapi ratapan kematian. Melalui kekuatan tersebut, perempuan dapat berkuasa terhadap dirinya sendiri dan laki-laki. Kekuasaan yang dipereoleh perempuan dari dalam dirinya tidak lantas membuat perempuan menjadi superior, melainkan terjadi kesetaraan arti keduanya. Kesetaraan arti tersebut bermakna lakilaki dan perempuan sama-sama memiliki nilai di masyarakat tanpa memandang gender tertentu. Melalui usahanya, perempuan mampu menyejajarkan diri terhadap laki-laki.

\section{DAFTAR PUSTAKA}

Australian Goverment. (2016). Gender equality and women's empowerment strategy.

Bolisani, E., \& Bratianu, C. (2018). The elusive definition of knowledge. In Knowledge Management and Organizational Learning (1st ed., pp. 1-22). United States: Springer International Publishing. https://doi.org/10.1007/978-3-31960657-6_1

Campbell, M. M., Hecq, D., Keane, J., \& Pont, A. (2015). May 68: Parodic rehearsals of the future in Lacan and Duras. Text, 33, 1-16.

Duras, M. (1970). Destroy, she said. (A. Darmawan, Ed.). Yogyakarta: Jalasutra.
Eisenstein, Z. (1979). Developing a theory of capitalist patriarchy and socialist feminism. In Z. R. Esenstein (Ed.), Capitalist patriarchy and the case for socialitst feminism (pp. 1-4). New York and London: Monthly Review Press.

Gamble, S. (2010). Pengantar memahami feminisme dan postfeminisme. Yogyakarta: Jalasutra.

Gumelar, R. G., \& Mukhroman, I. (2015). Tato: representatif gender dalam perspektif feminisme. Jurnal Kajian Komunikasi, 3(1), 71-80.

L. Mosse, G. (1996). The image of man : The reation of modern masculinity. New York: Oxford University Press.

O'Neil, T., \& Domingo, P. (2016). Women and power overcoming barriers to leadership and influence. London.

Pradopo, R. D., Soeratno, S. C., Sayuti, S. A., Wuradji, Supadjar, D., Faruk, ... Widati, S. (2003). Metodologi penelitian sastra. (Jabrohim, Ed.) (3rd ed.). Yogyakarta: Hanindita Hraha Widya.

Susilo, D., \& Kodir, A. (2016). Politik tubuh perempuan: bumi, kuasa, dan perlawanan. Jurnal Politik, 1(2), 317330.

Utomo, W. (2011). Gender inequality in Fatima mernissi's novel Dreams of Trespass (1994): a socialist feminist approach. Universitas Muhammadiyah Surakarta.

Wolf, N. (1997). Geger gender. Yogyakarta: Pustaka Semesta Press. 
Undas Vol 15, Nomor 2, Desember 2019: 123-134

Yoga, R., Akhmad, M., \& Dahri, D. (2018). Perjuangan tokoh utama dalam novel pelabuhan terakhir karya Roidah: kajian feminisme liberal. Jurnal Ilmu Budaya, 2(3), 221232. 